\title{
ТЕОРЕТИЧНІ ОСНОВИ ФОРМУВАННЯ ПЕДАГОГІЧНОЇ МАЙСТЕРНОСТІ МОЛОДИХ ВИКЛАДАЧІВ МЕДИЧНИХ УНІВЕРСИТЕТІВ
}

\author{
О. Б. Михалюк
}

\author{
ДВНЗ “Тернопільський державний медичний університет \\ імені І. Я. Горбачевського МОЗ України"

\section{THEORETICAL BASIS OF PEDAGOGICAL SKILLS FORMATION OF THE YOUNG TEACHERS AT MEDICAL SCHOOLS}

\author{
O. B. Mykhaliuk \\ SHEI "Ternopil State Medical University by I. Ya. Horbachevsky of MPH of Ukraine"
}

\begin{abstract}
У статті розглядаються питання формування педагогічної майстерності молодих викладачів медичних університетів. Подана роль педагогічної майстерності, професійної компетентності, професіоналізму для підвищення якості підготовки майбутніх лікарів і провізорів. Розкрита структура педагогічної майстерності: суб'єкт, об'єкт, предмет спільної діяльності, цілі, задачі, зміст, засоби комунікації. Схарактеризовано 10 груп педагогічних умінь, якими мають володіти викладачі. Розглянута роль таких компонентів навчального процесу як: гностичний, проектувальний, конструктивний, комунікативний, організаційний. Подана структура педагогічних технологій, які використовуються в навчальному процесі: концептуальна основа і змістова частина. Обгрунтовано наявні суперечності навчальної підготовки майбутніх фахівців між: задовільним рівнем педагогічної майстерності молодих викладачів ВНЗ та зростаючим обсягом навчального матеріалу з фахових дисциплін, якість вивчення яких не забезпечується традиційними методиками; вимогами до професійних якостей сучасного лікаря і провізора, його вмінь і навичок у прийнятті нестандартних рішень та недостатньою практикою професійної підготовки; необхідністю практичної готовності майбутніх лікарів і провізорів до дій у нестандартних ситуаціях та її забезпеченням використанням міжпредметно-інтеграційних, професійно-адаптаційних і особистісно орієнтованих підходів до професійної підготовки студентів.
\end{abstract}

The article deals with the aspects of pedagogical skills formation of young teachers at medical schools. The role of pedagogical skills, professional competence, professionalism in improvement of quality of future pharmaceutists and doctors preparation is presented. The structure of pedagogical skills is shown, that is subject, object, the subject of the joint activity, aims, tasks, content, and means of communication. The ten groups of pedagogical skills which the teachers should master are characterized. The role of learning process components (of gnostic, projective, constructive, communicative, organizational) is examined. The structure (conceptual basis and content part) of the pedagogical technologies which are used in learning process is presented. The actual contradictions of the training preparation of future specialists are grounded, that is between the following - the fulfilling level of pedagogical skills of young teachers at the universities and growing volume of studying material on specialty subjects, the quality of studying of which is not provided by the traditional methodologies; the requirements to the professional qualities of the future doctors and pharmaceutists, their skills and practices in nonstandard decision making and non-sufficient practice of professional preparation; the necessity of practical readiness of future doctors and pharmaceutists to the action in the nonstandard situations and its possibility to provide the use of intersubject and integrative, professional and adaptive, and personality-oriented approaches to the professional training of the students.

Вступ. Нині все більше уваги науковці приділяють підвищенню якості підготовки фахівців різного профілю. На даний час більшість вищих навчальних закладів готує майбутніх фахівців, які володіють задовільним ідостатнім рівнем знань. Але існуєпотреба у підвищенні якості підготовки фахівців до професійної діяльності. Це стосується і підготовки майбутніх лікарів і провізорів. На сьогодні, у зв'язку з бойовими діями на Донбасі, створені спеціальні групи медичних і фармацевтичних фахівців, які працюють у зоні

(C) О. Б. Михалюк
ATO. В містах, де є військові госпіталі, вони працюють 3 великим навантаженням, рятуючи захисників Вітчизни. Їм доводиться мати справу з випадками, до яких вони можуть бути не готові. Справитись 3 ними можна лише за наявності сформованих професійних умінь і навичок. Початок їх формуванню закладається ще у процесі навчання у навчальному закладі.

Якість професійної підготовки багато в чому залежить від сформованості професіоналізму, педагогічної майстерності викладачів, які беруть участь у підготовці фахівців лікувального чи фармацевтичного профілю. 
Тому сьогодні проблема формування педагогічної майстерності викладача досить детально розглядається вченими, педагогами: питання змісту, структури та виявів професійної майстерності (Є. Барбіна, І. Зязюн, Л. Ковальчук, Л. Крамущенко, В. Семиченко та ін.); творчих основ педагогічної майстерності (В. Кан-Калик, Н. Кичук, С. Сисоєва, О. Шупта); професійної компетентності викладача (Л. Ващенко, М. Жалдак, І. Зязюн, О. Локшина, Н. Ничкало, О. Пометун, Л. Романишина, О. Савченко, С. Сисоєва, О. Хуторськой та інші). Але проблема підвищення педагогічної майстерності потребує подальших досліджень, що обумовлено наявними суперечностями навчальної підготовки майбутніх фахівців між:задовільним рівнем педагогічної майстерності молодих викладачів ВНЗ та зростаючим обсягом навчального матеріалу з фахових дисциплін, якість вивчення яких не забезпечується традииійними методиками; вимогами до професійних якостей сучасного лікаря чи провізора, його вмінь і навичок у прийнятті нестандартних рішень та недостатньою практикою професійної підготовки; необхідністю практичної готовності майбутніх лікарів і провізорів до дій у нестандартних ситуаціях та її забезпеченням; використанням міжпредметно-інтеграційних, професійноадаптаційних і особистісно орієнтованих підходів до професійної підготовки студентів.

Тому метою статті ми обрали процес формування педагогічної майстерності молодих викладачів медичних університетів.

Основна частина. У вищій школі все більше використовуються інноваційні педагогічні технології. Їх використання не залежить від спеціалізації фахівців, оскільки є потреба в професійно компетентних спеціалістах. Тому зараз розробляється і використовується велика кількість педагогічних технологій у вітчизняній і зарубіжній практиці. Це висуває перед викладачами проблему: виокремити найбільш оптимальні, високоефективні технології. Але оволодіння ними потребує розвинутої педагогічної майстерності.

Питання педагогічної майстерності вивчали багато вітчизняних науковців і практиків педагогів (В. Андрущенко, В. Бех, В. Журавський, М. Згуровський, Б. Клименко, В. Лутай, М. Романенко, Н. Скотна, М. Степко, В. Цикін, В. Шинкарук та інші). Л. Анциферова, Л. Бабич, Г. Балл, Є. Барбина, В. Бутенко, І. Зязюн, Г. Кондратенко, Л. Крамущенко, I. Кривонос, Н. Кузьмина, М. Лазарєв, Л. Романишина, В. Сухомлинський та інші висвітлювали місце і роль педагогічної майстерності в системі професійних характеристик вчителя.
Існує чимало визначень педагогічної майстерності: "найвищий рівень педагогічної діяльності, який виявляється в тому, що у відведений час педагог досягає оптимальних наслідків" [4, 5, 7]; "високе мистецтво виховання і навчання" [2]; "синтез наукових знань, умінь і навичок методичного мистецтва і особистих якостей учителя" [11]. В. Куценко зазначає таке: "Педагогічну майстерність слід розглядати як цілісне соціально-психологічне утворення, що включає в себе певні взаємопов' язані й взаємообумовлені компоненти, що складають специфічну систему" [6].

Педагогічна майстерність - вияв високого рівня педагогічної діяльності. Для формування педагогічної майстерності необхідне розуміння структури педагогічної діяльності, яка базується на таких педагогічних підходах, як: структурний, функціональний, діяльнісний, рефлексивний. Н. Кузьміна виділяє п'ять основних структурних елементів педагогічної діяльності [3]:

- суб'єкт педагогічної діяльності;

- об'єкт педагогічного впливу;

- предмет їх спільної діяльності;

- цілі навчання;

- засоби педагогічної комунікації.

Ці структурні елементи подано на рисунку 1.

Поняття педагогічної майстерності набуває більшої конкретики і стає одним із базових понять педагогічної акмеології, хоча визначення поняття трактується по-різному [10].

Педагогічна майстерність характеризується групою педагогічних умінь.

Перша група охоплює вміння бачити в педагогічній ситуації проблему і формулювати ії у вигляді педагогічної задачі.

Другу групу становлять уміння працювати зі змістом навчального матеріалу, визначати міжпредметні зв'язки.

Третя група — уміння професійної самоосвіти та саморозвитку.

Четверта група - уміння оптимальної педагогічної комунікації, володіння прийомами реалізації внутрішніх резервів партнера у спілкуванні.

П'ята група охоплює вміння, які забезпечують високий рівень спілкування.

Шоста група - уміння підтримувати стійку професійну позицію педагога, який усвідомлює значущість своєї професії.

Сьома група складається зі здатності усвідомлювати перспективу професійного розвитку, визначати особливості свого індивідуального стилю, вміння максимально використовувати свій творчий потенціал. 


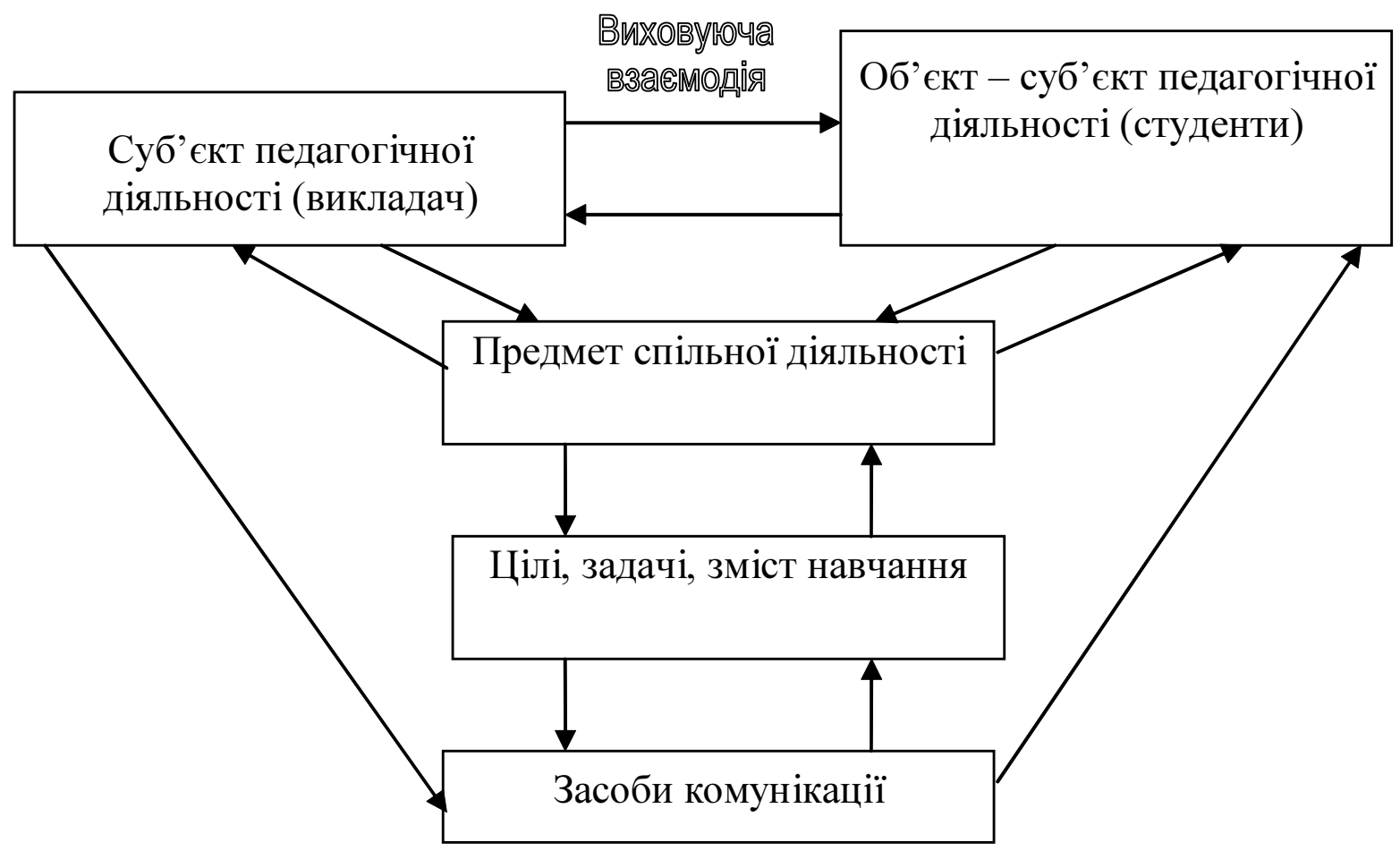

Рис. 1. Структурні елементи педагогічної діяльності (за Н. Кузьміною).

Восьма група — вміння: оцінювати продуктивність педагогічної діяльності; виявляти окремі показники вихованості та ефективності навчання.

Дев'ята група - оцінка викладачем рівня вихованості студентів; уміння створити умови для стимуляції достатньо розвинутих рис особистості студента.

Десята група - інтегральні вміння викладача оцінити власну професійну позицію, визначити свої сильні та слабкі сторони [8].

Велика роль у формуванні педагогічної майстерності належить компонентам навчального процесу та вмінням забезпечувати їх реалізацію. У працях Н. Кузьміної виділяються п'ять функціональних компонентів педагогічної діяльності: гностичний, проектувальний, конструктивний, комунікативний, організаційний. Кожний 3 компонентів виконує свою функцію і роль.

Гностичний компонент пов'язаний із сферою знань педагога. Йдеться про знання предмета, який він викладає, знання засобів педагогічної комунікації, психологічних особливостей студентів і особливостей власної особистості та діяльності.

Проектувальний компонент містить близькі та перспективні цілі навчання і виховання, а також стратегії та засоби їх досягнення.

Конструктивний компонент відображає особливості конструювання педагогом власної діяльності та діяльності студентів 3 урахуванням найближчих цілей навчання й виховання.
Комунікативний компонент характеризує специфіку взаємодії викладача зі студентом при досягненні дидактичної мети.

Організаційний компонент пов'язаний з умінням організувати діяльність студентів і власну діяльність [3].

Аналіз суті дефініції “професійно-педагогічнапідготовка викладача" свідчить про те, що у її тлумаченні $\epsilon$ дві складових: професійна і педагогічна. Це $\epsilon$ свідченням того, що не можна бути викладачемпрофесіоналом, не оволодівши педагогічною майстерністю. Ефективність впровадження педагогічних технологій залежить від цих двох складових.

Розрізняють такі поняття, як педагогічна технологія й освітня технологія. Освітні технології є стратегіями розвитку національного, державного, регіонального та муніципального освітнього простору. Педагогічні, як правило, відображають прийняті в різних країнах системи освіти, їх загальну цільову та змістову спрямованість, організаційні структури й форму, зафіксовані в державних нормативних документах, особливо в освітніх стандартах. Вони можуть об'єднувати інші спеціалізовані технології, застосовувані в різних галузях науки й практики, - електронні, нові інформаційні, поліграфічні, валеологічні та ін. [1].

За поданням Г. Селевка, педагогічна технологія це змістове узагальнення визначень різних авторів $\mathrm{i}$ характеризується трьома аспектами: 
1) науковим - як частина педагогічної науки, що вивчає та розробляє цілі, зміст і методи навчання, а також проектує педагогічні процеси;

2) процесуально-описовим - опис (алгоритм) процесу, сукупність цілей, змісту й методів навчання;

3) процесуально-дійовим - здійснення технологічного (педагогічного) процесу, функціонування всіх особистісних, інструментальних і методологічних педагогічних засобів [9].

Викладачі, які мають великий педагогічний досвід, не зустрічаються з тими труднощами, як молоді викладачі. Тому для молодих викладачів потрібно проводити спеціальні семінари з новітніх педагогічних технологій, з засобами проведення занять. Технологія “занурення”, яка використовується в Тернопільському державному медичному університеті імені I. Я. Горбачевського, потребує від викладачів великої майстерності, і не тільки педагогічної. При впровадженні цієї технології молоді викладачі повинні бути готовими до низки труднощів і знати, як їх усунути.

На нашу думку, молодим викладачам, які працюють за цією технологією, необхідно:

1. Швидко ставати професіоналами, мати сформовану професійну компетентність.

2. Володіти добре розвинутою комунікативною компетенцією.

3. Вміти застосовувати інформаційні технологіі, володіти сучасними засобами навчання.

\section{Списоклітератури}

1. Бодруг Н. А. Роль педагогічної майстерності вчителя в умовах реалізації Болонського процесу / Н. А. Бодруг // Проблеми підготовки сучасного вчителя: зб. наук. праць Уманського державного педагогічного університету імені Павла Тичини / [ред. кол.: Н. С. Побірченко та ін.]. - Умань : ППЖовтий О.О., 2011.-Вип. 4, ч. 1.-С. 292-298.

2. Педагогічна майстерність : підручник / [I. А. Зязюн, Л. В. Карамущенко, І. Ф. Кривоніс та ін.] ; ра ред. І. А. Зязюна. -2-ге вид., допов. і перероб. -К. : Вища шк., 2004. -422 с.

3. Кузьмина Н. В. Очерки психологии труда учителя / Н. В. Кузьмина. - Л., 1967.-С. 54-62.

4. Кузьмина Н. В. Профессионализм деятельности преподавателя и мастера производственного обучения профтехучилища / Н. В. Кузьмина. - М. : Высш. шк., 1989. - 167 с.

5. Курлянд 3. Н. Педагогіка вищої школи : навч. посіб. / 3. Н. Курлянд, Р. І. Хмелюк, А. В. Семенова. - 3-тє вид., перероб. і доп. -К. : Знання, 2007. -495 с.
4. Вміти знімати психологічну напругу в аудиторії, оскільки спілкування з одним і тим же викладачем протягом шести годин викликає певне напруження, особливо коли не зовсім дружні відносини у викладача з аудиторією.

5. Добре володіти прийомами переведення уваги з однієї проблеми на другу.

6. Вміти підтримувати зацікавленість студента в засвоєнні матеріалу.

7. Обирати найбільш доцільні методики проведення занять за різними темами, але з однієї дисципліни.

Формувати власну педагогічну майстерність можна декількома шляхами: відвідувати заняття більш досвідчених викладачів, знайомитись з особливостями різних технологій на сторінках педагогічних і медичних журналів, брати участь у науково-методичних конференціях викладачів вищих навчальних закладів, розробляти методичні рекомендації з використанням новітніх засобів навчання, розробляти тестові варіанти для автоматизованого контролю навчальних досягнень студентів.

Висновок. Таким чином, проблема формування педагогічної майстерності молодих викладачів медичних університетів залишається потрібною, на часі, а тому буде продовжуватися. Це входить у план наших подальших досліджень.

6. Куценко Т. Особливості нетрадиційних форм уроку англійської мови / Т. Куценко // Психолого-педагогічні проблеми сільської школи. -2013. - Вип. 46. -С. 106-110.

7. Кухарев Н. В. На пути к профессиональному майстерству / Н. В. Кухарев. - М. : Просвещение, 1990.-С. 124.

8. Маркова А. К. Психология труда учителя / А. К. Маркова. - М., 1993.-191 с.

9. Селевко Г. К. Современные образовательные технологии : учебное пособие / Г. К. Селевко. -М., 1998. - 256 с.

10. Стефановская Т. А. Педагогика: наука и искусство / Т. А. Стефановская. - М. : Совершенство, 1998. - 368 с.

11. Щербаков А. И. Формирование личности учителя в системе высшего педагогического образования : автореф. дис. доктора пед. наук / А. И. Щербаков. - Л., 1978. - 25 с.

Отримано 06.02.15 